\title{
Semiotic and Synergistic Approaches in the Study of Musical-Theatrical Productions as Synthetic Art Texts
}

\author{
Svetlana Iu. Lysenko* \\ Khabarovsk State Institute of Culture \\ 112 Krasnorechenskaia Str., Khabarovsk, 680045, Russia
}

Received 26.01.2016, received in revised form 17.02.2016, accepted 23.04.2016

In today's art criticism there is an increasing necessity in searching for new methodological approaches to the analysis of literary texts, based on the synthesis of various art forms. This paper highlights the need for an integrated approach to the study of musical and theatrical genres (opera and ballet), taking into account the stage interpretation phase. For this sake musical-theatrical work is regarded as a synthetic literary text, understood as the result of a gradual multi-level interpretation of the text from literary source (the composer creativity phase) and interpretation of the musical score (the staging incarnation). The semiotic approach can explain the multiplicity of meanings in a musicaltheatrical text - both the original and interpretative source; reveal the text intention as generating meanings, the text being seen as an incentive to the emergence of new staging versions. For the first time ever to analyze the musical and theatrical genres the author used a synergistic ap-proach that allows understanding the synthetic literary text of Opera/Ballet as an open system with features of self-organization. At the same time artistic interpretation of the composer and producers is considered a manifestation of its instability and the subsequent establishment of a new order in the newly formed text (whether it is a composer score, opera or ballet performances).

Keywords: literary text, musical-theatrical genre, opera, ballet, the synthesis of arts, artistic interpretation.

DOI: 10.17516/1997-1370-2016-9-6-1399-1409.

Research area: art history.

From their birth musical and theatrical genres have always been in the center of artistic and research attention, largely due to the special trait of the synthetic nature of these genres, initially oriented on the complex sensory perception in the course of theatrical stage implementation.

The most significant genres in the variety of musical and theatrical ones include opera and ballet. Opera genre, according to the researchers, has a mysterious many-sided nature of poetic, musical and dramatic whole, unique artistic effects, amazing ability to revive despite numerous crises of the genre, sensitivity to the needs of time and degree of the reverse impact on culture and society that provokes the modern creators and interpreters to feel inexhaustible need

(C) Siberian Federal University. All rights reserved

* Corresponding author E-mail address: 1sy773@mail.ru 
to return to opera classics, the desire to continue the cultural dialogue with the opera tradition. The urgency of our attention to the genre of ballet in the aspect of synthesis is due to a significant change in its status concerning the art of the last century. Ballet in the $20^{\text {th }}-21^{\text {st }}$ centuries has become one of the most popular genres, which, along with opera and symphony, enables deep philosophical and conceptual generalizations, and which has the power and persuasiveness of artistic influence, comparable to opera and cinema impact. Moreover, in modern musical theatre it is a genre of ballet, which becomes a kind of a testing ground for new forms of interpretative work (of primarily choreographers, directors, ballet-masters) with the author's text.

It seems that these reasons let opera and ballet remain in the focus of modern artistic searches, so stipulating the need to continue scientific reflection about the special quality of the opera and ballet synthesis in the aspect of artistic interpretation.

In the context of musical research tradition opera and ballet are commonly defined as specific musical and theatrical works based on the synthesis of various art forms, their means of expression. The opera shows a synthesis of lyrics, music and stage action, in the ballet there is a combination of music and choreography. In these genres music becomes the main element and the driving force behind the action. For a long time opera and ballet as a musical and theatrical works have been treated by Russian musical aesthetics as a result of composing activity, limited within historical and cultural framework. They have been characterized by an internal integrity, motivational character of the whole, the individual content and form, which demonstrate the unique personality of the author and a detailed fixation in musical score, presupposing the highest level in performing interpretation (Cherednichenko, 1991, p. 141). The above-mentioned specifics of musical and theatrical work is realized in a synthesis of various art forms involved in the genres of opera and ballet for the embodiment of an entire artistic idea.

These definitions seek to reach out to all components of opera and ballet as musical and theatrical works, but specifying opera and ballet in the classical tradition of aesthetics, these definitions do not take into account their important communicative traits. Among them there is the ability to relate to other texts of culture, openness to the intertextual connections, as well as the possibility of implementing of the creative ideas by their interpreters. These properties are conditioned by sense-making nature of their creative perception, that is, everything that is usually attributed by the modern humanities to the essential characteristics of the text culture.

We shall note that the communicative approach to the work is in line with the semiotic understanding of the text. A look at a piece of music from the perspective of its communicative functions, easily projected on the musical and stage work, makes it possible to distinguish three aspects of probable consideration: 1) the artistic communication (the work cannot be confined to the musical text or sound process only, it is rather an object, whose structure reflects the structure and peculiarities of a particular genre model, correlated with the stylistic context);2) the recording of the material (musical notation, the performing process, and others); 3 ) the perception, which takes into account the specific structure in the work, which comprise cultural, historical, perceptual, personal, psychological factors, the depth of spectators' "reading" which depends on their cultural experience (cf. (Nazaikinskii, 1982, p. 36). The last of these aspects reflects such essential characteristics of the text as the emotional and personal nature of perception, intertextuality, the ability of the work to plunge the viewer-listener into a "dialogue 
of cultures", the possibility of immersing in the cultural and historical context specific for the genre, and others.

However, this approach to understanding a musical work does not reveal the theatrical and the scenic nature of the genres chosen for analysis in our work, and does not allow us to consider the process and result of interaction between the author's intention and its staging interpretations. This approach does not take the advantage of the semantic multiplicity of musical and theatrical text - the author's and interpretative source; it does not take into account the meaninggenerating intentions of the text as an incentive to the new staging options, new semantic versions of the scenographic solutions, the new director's readings. These aspects of the analysis take the temporal (processual) existence of musical works into account only partly, this works being a part of the cultural, evolving in time society.

In addition, in the terminology of modern scientific paradigm, notions of opera and ballet as works actualize the centrality of their semantic structure, presupposed by the author's reputation and/or text codes. Opera and ballet thus function as a relatively stable and complete semantic structure, organized with the aim of presenting to the recipient. This approach does not seem to fully take into consideration the dialogical conception of art, which we strive to make explicit in the present paper, heeding the variative multiplicity of staged interpretations in the modern musical theater practice. Analyzing opera and ballet, equating them to the works and paying no attention to the complexity of the extra-textual relations is the same thing, according to Yu. Lotman as "considering the act of communication, ignoring the problems of perception, code, interpretation< ... >, reducing it to a unilateral act of speaking" (Lotman, 1994, p. 213). A look at opera and ballet as works that have meaningful and determinate completeness definitely breaks (stops) "the text chain" (Bakhtin) of culture, where "there can be neither the first nor the last sense, this sense is always between meanings, just a link in the semantic strand" (Bakhtin, 2002, p. 410).

In summary, here we should follow $\mathrm{M}$. Aronovskii, whospecified that the relation between concepts of "work" and "text" is just a reflection of "different perspectives of looking at one artifact", so "work" and "text" are only different forms of existence of a cultural phenomenon (Aranovskii, 1998, p. 24). Opera and ballet as works "have already taken place" both in musical and symbolic form, and in the representation and perception. Opera and ballet as texts "are happening now", acquiring more and more new staging and interpretative versions. This position brings us closer to understanding musical and theatre genres as texts capable of self-development, of expanding their meaning horizons in discourse of interpretative readings. Musical and theatrical work includes the traditional for the last century musicology dialogue between "a composer", "an interpreter" and "a listener". Opera and ballet as texts, being "connected" to the text of culture via interpreting and implementing intertextual traits of meaning-generating perception, are in charge of the dialogue between the "ages" and the "nations" (Lotman). It is dialogic nature of artistic interpretation, receiving an additional dimension in musical and theatrical genres, which does not allow us to equate "work" and "text".

It should be noted that the Russian musicology in line with the especially fruitfully developing in the last decade semiotics carries out a new approach to textual analysis of musical and theatrical productions. Thus, in a number of studies opera appears as a specific sign system with a deep immanent sense, encoded on external sign level of the text. Revealing these deep layers of meaning through a special analysis procedure can discover archaic cultural codes in particular, which contribute to "plunging" of the opera-text 
into an "unaccomplished dialogical context" (Bakhtin). This approach gets a form of rigorous methodological procedures in the stratification method proposed by S. Goncharenko, who differentiated levels, layers and strata of the text (Goncharenko, 2010, p. 20). During the consistent description of semantic genre strata on the example of opera text the researcher discovers upper (social and modern), deep (folk and mythological) and central (art) opera layers, the latter 'absorbs, gathers, and 'intercrosses' semantic ideas of each of the layers".

Expansion of methodological procedures during the analysis of textual features in opera and ballet in the culture context also takes place through the involvement of intertextual strategy, which receives now wide coverage in musicological works. Comprehension of semantic ambiguity in musical and theatrical texts can occur through its inclusion either in the "breeding ground" of intertextual connections in the genre, characteristic of a particular composer; through the (auto)biographical text of the creator's art and life; through the social and cultural context, which either "gave birth to" the musical and theatrical text or interpreted it somehow. Along with this researchers can trace a wide range of cultural and historical intertextual ties in musical and theatrical works at various levels, including genre, plot, image, stylistic, and linguistic levels.

One may emphasize that the semiotic analysis of musical and theatrical genres opens a new way to cover traditional musicology issues of the relationship between literary source and the libretto; relationship between scenic and musical drama; issues concerning the features of the composer's thinking in the context of the composer's works, within the national school, and within the genre tradition. Such approaches to the opera and ballet analysis make researchers refocus attention on the problem of the text understanding and richness of its interpretation. Scenic life of the synthetic text reveals this problem vividly, since, for example, a plurality of staging concepts of the same opera text "plainly proves polysemy in the opera score" (Goncharenko, 2000, p. 15).

The difference and at the same time complexity of the analysis of synthetic musical and theatrical genre as a text having polysemic organization, according to the researchers, is precisely in capability to place the various methods of analysis, corresponding to different sign and language areas, i.e. musical, visual and verbal, into a single system (Goncharenko, 2010, p. 19-20). In semiotic approach an important method is the analysis of the synthetic nature of musical and theatrical sign, as it allows the sign system of relations between its differentquality components to change in the process of performance. Thus, the synthetic nature of the sign in the music and theatrical text ("a sign triangle"), which S. Goncharenko observes on the opera example, gives an opportunity to distinguish in it three different quality sigh spheres, which the composer "wraps" in the sign, i.e. in music, word, and action. As the researcher explains, a traditionally dominant position of music in opera score "accommodates" the functions, meanings of the words and actions (the characters' actions, movements, gestures, facial expressions, etc.) in the musical part of the sign. However, during the life on stage the sign is "disclosed", "releasing the potential energy of the musical theme in the kinetic energy of a synthetic image of the performance" (Goncharenko, 2000, p. 16).

This process, which we understood as a change of the system of interrelations between the different meaningful (semantic) components in the synthetic sign unit of the opera text, stage productions, as expected, gets its visual realization in the performance. This performance possesses greater freedom in comparison with the musical and verbal realization. Let us assume that the visual components of a macro-sign (the 
term was proposed by S. Goncharenko) highlight the synthetic nature of the opera text sign; macrosign combines signs of different nature, different types - iconic, linguistic, musical. Implemented in stage and scenographic action these signs contribute to the identification (opening) of the layers of the internal structure in the opera text in the process of its production (Goncharenko, 2010, p. 19).

Inthemeantime, theproblemoftherelationship between semantic layers (components) of the sign only indirectly addresses the issue of the relations between the author's intention, encoded in terms of signs in the musical and theatrical text, and its staged "re-expression" in the visual range of the performance. In light of the continuously raised here problem of verbal interaction between the source, the musical score and interpretation a semiotic approach to the opera and ballet analysis as special literary texts shall be supplemented with the conceptions of the meaning-generation nature of artistic activity involving interpreters. This matter is the subject of hermeneutics studies. Moreover, the hermeneutic tradition of "interpreting texts" is based on the notion of the text as a special semantic space, which carries out a "dialogue of consciousnesses" (Bakhtin), which makes it possible to see the interpretation not only as recreation of the author's idea, but also as the meaning-generation process.

Given the synthetic nature of the musical and theatrical genres that focus on complex sensory perception and perform multiple interpretative procedure of meanings' re-expression, it is likely to see opera and ballet as synthetic literary texts. This term has relatively recently been introduced in the range of textual concepts by the philologist-hermeneutic G. Bogin. Considering a verse component in the cinematic synthesis, he concludes that the synthetic text of the culture is not only the result of the synthesis in various art forms, Here the realization of an artistic idea in the minds of recipients is made by the means of poetry, music, cinema, visual art related to set design, costumes, interior, etc. (Bogin, 1997, p. 22). More important is that each of the components of such a text, representing a certain kind of art, is the carrier of its meanings in their hermeneutic understanding.

The synthetic text of culture found its continuation in the term "synthetic art text" used in a number of papers by P. Volkova. Taking the idea of G. Bogin on components of the synthetic whole as meaning bearers the researcher applies it to the analysis of music works: in chamber vocal genre (Volkova, 2001) and in opera (Volkova, 1997). Next we will describe the scientist's conclusions will be guided by them in our analysis of synthetic art texts of (hereinafter referred to as SAT), adding the ballet genre to the list of such texts:

1. The multi-stage structure of SAT creation each subsequent component of the synthetic whole process is the result of interpretation of preceding texts. In particular, in opera libretto becomes the result of interpretation of the literary (poetic) source, while musical score puts its semantic accents regarding the verbal text. Thus, the composer creates a new artistic whole based on the poetic text. Projecting this conclusion on the ballet genre allows us to imagine the composer's score as a result of the interpretation of a literary source. In turn, choreography in ballet is born in the process of rethinking the musical text.

Thus, the researchers thinks that within SAT gets its resolution the problem of the unity of text and context, "given" and "created", cognitive and ethical, where "the text is cognitive and given" and "the context is created and ethical". These are the characteristics of the text as a carrier of conceptual information, implemented in external sign form of a language (verbal or musical), and the characteristics of the context as creative individual and personal thinking of the composer, 
director and choreographer, who are able to realize the emotional meaning of the perceived text (Volkova, 2001, p. 58).

2. The musical interpretation in SAT translates the understood author's idea from one conceptual and sign system into another. At the same time the process of the text derivation appears as "the formation of new meanings, constructed with the original signs of a verbal language and actualized in an averbal language" (Volkova, 1997, p. 3), i.e. in the musical intonation or in dance performance.

3. Based on the opera analysis as SAT, considered in the aspect of interaction between verbal and music means, the researcher concludes that there is a means of the meaning interpreting in a literary text. This means is the general characteristic of the involved sign systems and a prerequisite for their cooperation. This means of the identification of the semantic signals in the text creates the conditions for a "dialogue of consciousnesses", updates the semantic intention in the interpreted text, specifies its meaningful multiplicity.

Philology perspective in the analysis of the submitted texts in the works of P. Volkova increases the "specific weight" of the verbal forms of interpretation, primarily at the opera libretto level. Musical and intonation components are seen as the explication means, aimed at the interpretation of the semantic potentials of the verbal text. With respect to ballet the already named links in the interpretative process have one more step, namely choreographic reading, which can be considered as a meaningful re-expression of a musical score.

However, the interpretative chain in the SAT analysis can be extended, if we consider SAT from the perspective of the subsequent actual performance and include it in the discourse of rendition. Then the implementation of the opera and ballet communicative function in semantic interpretative process involves theatrical, stage, musical, performative, and audience interpretations. To regard SAT in the aspect of artistic interpretation and analysis of the interaction of the author's text and its theatrical and stage renditions we reckon it possible to allot the performative aspect of all these kinds of interpretations. We shall stress that in the result of the stage implementation of the musical and theatrical whole as SAT there appear new texts with the sign systems of different nature and with their own coding means. At the same time, it should be emphasized that the range of non-verbal sign systems expands considerably. These sign systems are involved in decoding the meaning of the original verbal text. Consequently, the objectification of the interpretation process result can occur not only through words (libretto), sound (composing and performing musical intonation in the text), plastic art (choreography), but also through color, line, light (set design), gestures, facial expressions (special behavior of the actors), and so on.

Weshallcallattentiontothatwhenconsidering SAT as the phased multi-level interpretative processes we get semantic projections on the ideas about the text, formed within synergistic approach, where the text is interpreted as a complex open meaning-generation system which at all levels provides a mutual information and energy exchange and which has a "multiplying effect" in the final art result. This understanding leads us to consider SAT as a synergistic object that has its own specific features ${ }^{1}$.

The first noteworthy fact is that each preceding step in SAT (verbal text, musical score, choreographic interpretation, directorial concept) is the source (author's) text for the subsequent stages of the formation of the whole, which reveals in the subsequent interpretative procedures, plunging the system in a state of creative and dynamic chaos ${ }^{2}$. This process is accompanied by 
a state of extreme instability, because every time a relatively stable structure of the source text is subjected to "synergistic stirring up", deliberate destabilization of the interpretative process so that to organize itself into a new semantic structure of the interpretative text. We underline that these processes occur in SAT repeatedly, which complicates significantly the relationships within the system. The researcher's task seems to be the search for a constructive analysis of the transition mechanism from chaos to order.

SAT complexity as a synergistic phenomenon lies in the fact that evolving in time and space, it often demonstrates the historical and cultural distance between essential links in the interpretative chain. Such distance, as was shown earlier, realizes the text's connection to Culture text, facilitating information and energy exchange, having been comlexified in the process of human society development. The researchers who study synergistic process in culture state that during the information development, with the increasing role of information in the modern world the diversity of system reaction grows too (Ryzhov, 2002, p. 175). We shall remark here that this factor can explain such a diversity of modern interpreters' works regarding the original classical texts and such a multiplicity of interpretative readings.

Let us continue this line in reference to SAT. The researchers believe that the constant growth of culture information importance promotes the perfection of reflective processes, in particular, in interpretative procedure, which enables projecting a notion of creation as "pyramidal hierarchical structure of production, shot through with reflective processes" (Ryzhov, 2002, p. 175) on SAT creation process, ideating it as a complex system of multi-level creative search. During SAT analysis the researchers' attention is drawn not only to the results of interaction between different kinds of art, but also to the emergence of the synthetic whole with meaning fixation.

The nonlinear character of processes occurring during SAT creation and realization is testified in multiple relations between SAT elements, "the number of these relations can increase faster than the number of elements themselves" (Budanov, 2000, p. 294). Let us presume that in SAT there is a relation between signals coming from the text to interpreters, and semantic vectors directed from the interpretative texts inside the original source, whether it is verbal or musical text, allowing discerning and catching deep meaning layers, which have not been noticed before. Thus, in SAT system there are not only direct and linear relations coming from the text to interpreters and following the chronologic order, but also a plenty of feedback relations. This feedback communication may either further the system development process, or stable the system. From the standpoint of synergetics the first aspect is a positive factor, while the second bears negative consequences for self-organizing systems. In such a way SAT demonstrates various probable types of paths in the multi-level text structure.

In our opinion in the tideway of acceleration there are such trends when interpreters-stage directors return to the literary source, "passing" the nearest (intermediary) link in SAT. By this they do not realize all conceptual relations in the composer's text, who has already produced his/her own interpretation of the verbal text and presented the result in the synthetic text of musical score. Such process might occur at the stage of creating musical score, when the composer "fuels" his/her interpretation not from the literary source, but from those texts, which became the "breeding ground" for a poet (writer) and were the original basis for literary interpretation. For instance, N. Rimsky-Korsakov in his fairy and mythological operas employed 
plots and concepts from Russian fairy-tales, out of A.S. Pushkin fairy-tales collection ("The Tale of Tsar Saltan", "The Tale of the Golden Cockerel"). P.I. Tchaikovsky in "The Queen of Spades" "makes a back leap in time", leaving the context of Pushkin time (the beginning of the $19^{\text {th }}$ century) and "turns" to another age, time of W.A. Mozart and A.E.M. Gretry. M.P. Musorgsky goes "beyond" A.S. Pushkin, including in his libretto of "Boris Godunov" historic archive documents of the $17^{\text {th }}$ century, which are extraneous for the verbal source (Scene "Near Kromi”").

This "leap back" at different levels of SAT, including modern performances, is conceivable if we recall some provisions of post-modern text concept, close to synergistic perceptions. In particular, text in J. Derrida deconstruction theory is a potential multiplicity of meaning possibilities, as a letter, whose creases are "inhabited" by covert, "sleeping" meanings awaiting for their time to be understood, interpreted. These meanings can be discovered only in future against the background of significant historic and cultural distance, in dialogic questioning context (See in detail: (Lysenko, 2014)).

Finally, to understand specific artistic interpretation within SAT (in its synergistic dimension) we should perceive the creative process as nonlinear synergistic system, which got its coverage in recent scientific papers. From the synergistic view the creative process should be perceived as a selection of meanings from semantic branching at the stage of intent, as a formation of order from the chaos of multiple possibilities for text development. Nevertheless, not realized possibilities do not disappear without a trace, rather they manage the process of meaning movement inwardly, urging it to a new meeting between actual and potential meanings (Sintsov, 2003 , p. 14). Invasion of potential meanings, as scientific synergetics adherents see it, occurs in any text. They are compared to "bifurcation points", where thinking acquires a new spectrum of possibilities. Through them, according to E. Sintsov, "everything created gets the chance to influence the next meaning movement and vice versa: future possibilities get the chance to influence the realized versions, "branched" (Sintsov, 2002, p. 87). Based on the given reflection, let us conjecture that characteristic in SAT turn of the interpreters to such "bifurcation (choice) points" (E. Sintsov), to such "point" of the author's text, where there are traces of the rejected ("cut") by the creator possibilities of meaning revealing, can be seen as resonant influence on the point of unstable balance of the text (bifurcation point). This bifurcation point enables synergistic SAT system to choose another way of meaning disclosure in interpretative texts.

So, probably, one of the leading notions of synergetics is present in SAT as a synergistic phenomenon: in a nonlinear medium all its future states are preset, but only one is realized (at the bifurcation point) (Ryzhov, 2002, p. 181). Then the new semantic versions of the interpreted text appear as the result of the bifurcation (during the choice of development ways). They are unpredictable, unexpected, but at the same time available versions in a spectrum of possible (potential) conditions. So, within SAT an additional emphasis is on the conclusion that the present (conventional analysis point, whether it is the musical score, the choreographic text or the theatrical and performative realization) is determined not only by the past (say, the original text, the source), but is also produced from future (the subsequent interpretation).

So, within the synergistic paradigm SAT is a single creative process of meaninggeneration and the creation of the literary text as the structuring of probabilistic and chaotic perception of artistic minds of all participants in a multi-stage interpretative procedure. The mechanism of creative thinking here is the self- 
organization mechanism that occurs at all "birth" stages of the synthetic whole. Complemented with hermeneutical notions of meaning-generation interpretation, the process of SAT creating can be represented as follows: the continual experience of the creator at every stage of the interpretative procedure, fixed in a relatively stable semantic structure of the source text, embodied in the semantic units, structures, methods of writing and expressed by language means in certain art, re-expresses itself in the individual coordinate system of interpreter's artistic consciousness. In the realization process such meanings (semantic knots) are peripheral, central, real, potential, free (terms proposed by Iu. Nigmatullina). These knots appear at the intersection of semantic lines in highly hierarchical meaning structure of the text. Apparently they can change their structural functions, contributing to re-emphasizing and "stirring up" of the stable semantic structure.
Following this understanding a new version of meaning is re-expressed by non-verbal means in the interpretative texts, such as composer's (sound), choreographer's (plastic art), scenic (gesture, mimics), scenographic (colour, line, light, etc.).

Thus, the study made revealed that the musical and theatrical genre as SAT is able to appear as a process and the result of a multilevel interpretation, gradually revealing in the chain of interpretative readings - composer's, director's, choreographer's ones, and in acting, choreography, set design. Within semiotic and synergistic approach such text is interpreted as a complex system, fundamentally open to dialogue with the cultural context and interpreters. This system is capable of multiple semantic renewal, with multi-level exchange of information taking place in conjunction of the system's elements.

1 These signs of synergistic systems further projected on synthetic art texts are the result of the generalizations found in the following works: (Budanov, 2000; Nigmatullina, 2008; Ryzhov, 2002; Sintsov, 2002). It should be noted that synergetic approach is just beginning to be introduced into scientific musicology. One of the first studies in this direction was the study of N. Koliadenko in which for the analysis of non-classical musical texts the researcher used such synergistic notions as self-organization, nonlinearity, the energy exchange, probabilistic connection of the elements, the constructive role of the creator of "dynamic chaos", "small resonant impact" (Koliadenko, 2005, p. 74-81).

2 Let us recall that in a synergistic paradigm the concept of chaos characterizes the processes of updating stable, orderly system, and has a positive and creative potential.

\section{References}

Aranovskii, M.G. (1998). Muzykal'nyi tekst: Struktura i svoistva [Musical text. Structure and characteristics]. Moscow, Kompozitor, 343 p.

Bakhtin, M.M. (2002). Sobranie sochinenii: V 7 t. [Collection of works: In 6 Vols], 6. Moscow, Rus. Slovari; Iazyki Slavianskoi Kul'tury, 800 p.

Bogin, G.I. (1997). Protsess smysloobrazovaniia pri retseptsii sinteticheskogo khudozhestvennogo teksta [Meaning-generation process in reception of literary text], In Vzaimodeistvie iskusstv: Metodologiia, teoria, gumanitarnoe obrazovnie [Interaction of arts: Methodology, theory, humanitarian education]. Astrakhan, 18-24.

Budanov, V.G. (2000). Transdistsiplinarnoe obrazovanie, tekhnologii i printsipy sinergetiki [Trans-disciplinary education, technology and principles of energetic], In Sinergeticheskaia paradigma. Mnogoobrazie poiskov i podkhodov [Synergistic paradigm. Diversity of search and approaches]. Moscow, Progress. Traditsii, 285-304.

Cherednichenko, T.V. (1991). Proizvedenie muzykal'noe [Musical work], In Muzykal'nyi entsiklopedicheskii slovar' [Musical encyclopedic dictionary]. Moscow, Sov. Entsiklopediia, 141. 
Goncharenko, S.S. (2000). O dvukh printsipakh semioticheskogo opisaniia opery [On two principles of semiotic opera description], In Sibirskii muzykal'nyi almanakh [Siberial musical anthology]. Novosibirsk, 15-21.

Goncharenko, S.S. (2010). O poetike opery [On opera poetics]. Novosibirsk, Novosib. Gos. Konservatoria, $260 \mathrm{p}$.

Koliadenko, N.P. (2005). Sinestetichnost' muzykal'no-khudozhestvennogo soznaniia (na materiale iskusstva XX veka) [Synesthesia of musical and artistic consciousness (on the basis of the $20^{\text {th }}$ century art]. Novosibirsk, $392 \mathrm{p}$.

Lotman, Iu.M. (1994). Lektsii po strukturnoi poetike [Lectures on structural poetics], In Iu.M. Lotman i tartusko-moskovskaia shkola [Iu.M. Lotman and School of Moscow and Tartu]. Moscow, Giozis, 213.

Lysenko, S.Iu. (2014). Postanovochnaia interpretatsiia v sovremennom muzykal'nom teatre: strategiia dekonstruktsii [Performing interpretation in modern musical theatre: deconstruction strategy], In Sovremennye problemi nauki i obrazovaniia [Modern problems of science and education], 1.

Nazaikinskii, E.V. (1982). Logika muzykal'noi kompozitsii [Logics of musical composition]. Moscow, Muzyka, 319 p.

Nigmatullina, Iu.G. (2008). Sinergeticheskii aspekt v issledovanii khudozhestvennogo tvorchestva [Synergistic aspect in research of artistic creation]. Kazan, Izd-vo Fen AN RT, 92 p.

Ryzhov, V.P. (2002). Informatsionnye aspekty samoorganizathzii v iskusstve [Information aspect of self-organization in art], In Sinergetichskaia paradigma. Nelineinoe myshlenie v nayke i iskusstve [Synergistic paradigm. Nonlinear thinking in science and art]. Moscow, 156-182.

Sintsov, E.V. (2002). Sinergeticheskie aspekty protsessov khudozhestvennogo myshleniia [Synergistic aspects of art thinking processes], In Voloshinova, A.V. (eds.) Sinergiia kul'tury [Synergetics of culture]. Saratov, 85-88.

Sintsov, E.V. Nevyrazimoe $\mathrm{v}$ iskusstve kak predmet nauchnoi i khudozhestvennoi refleksii. Perspektivy razvitiia sovremennogo obshestva: iskusstvo i estetika. Kazan, 2003. Ch. 4. S.11-20.

Volkova, P.S. (1997). Emotivnost' kak sredstvo interpretatsii smysla khudozhestvennogo teksta (na materiale prozy N. Gogolia i muzyki Y. Butsko, A. Khol'minova, R. Shchedrina) [Emotivity as a means of meaning interpretation in art text (on the basis of prose by N. Gogol, music by Yo. Boutsko, A. Kholminov, R. Shchedrin], In Avtoref. dis. ... kand. filolog. nauk [Thesis of Dissertation of Candidate of Philological Sciences]. Volgograd, $23 \mathrm{p}$.

Volkova P.S. (2001). Ritoricheskie modeli gumanitarnogo obrazovaniia [Rhetorical models of humanitarian education]. Moscow, 189 p. 


\title{
Семиотический и синергетический подходы
}

\section{в исследовании музыкально-театральных произведений как синтетических художественных текстов}

С.Ю. Лысенко

Хабаровский государственный институт культуры Россия, 680045, Хабаровск, ул. Краснореченская, 112

\begin{abstract}
В современном искусствознании все большее значение приобретает поиск новых методологических подходов к анализу художественных текстов, основанных на синтезе различных видов искусства. Данная статья актуализирует необходимость комплексного под-хода к изучению музыкально-театральных жанров (оперы и балета), учитывающего этап по-становочной интерпретации. Для этого музыкально-театральное произведение рассматрива-ется как синтетический художественный текст, понимаемый как результат поэтапной многоуровневой интерпретации текста литературного первоисточника (этап композиторского творчества) и музыкальной партитуры (постановочное воплощение). Семиотический подход позволяет объяснить смысловую множественность музыкально-театрального текста - как авторского, так и интерпретаторского; раскрыть смыслообразующие интенции самого текста как стимула к порождению новых постановочных вариантов. Впервые для анализа музыкальнотеатральных жанров привлекается синергетический подход, позволяюший осмыслить синтетический художественный текст оперы/балета как открытую систему, обладающую признаками самоорганизации, а художественную интерпретацию композитора и постановщиков - как проявление моментов ее неустойчивости и последующей организации нового порядка во вновь сформированном тексте (композиторской партитуре, оперной или балетной постановке).
\end{abstract}

Ключевые слова: художественный текст, музыкально-театральный жанр, опера, балет, синтез искусств, художественная интерпретация.

Научная специальность: 17.00.00-искусствоведение. 